\title{
The Meaning of Constructivist Approach in Mediation and the Role of the Mediator
}

(DViktorija Portere ${ }^{1} \mathrm{Mg}$. jur.; (D) Baiba Briede ${ }^{2}$ Dr. paed.

Latvia University of Life Sciences and Technologies, Latvia viktorija.portere@gmail.com ${ }^{1}$; baiba.briede@1lu.lv²

\begin{abstract}
The process of overcoming a conflict in mediation using constructivist ideas is revealed in the study. A mediator's roles in the frame of the constructivist approach represent the topicality of the study. The mediator's role is analysed and the emphasis is on the constructivist frame. The mediator's pedagogical role is in the centre of the study. In the process of the study, the aim was to find out theoretical explanations of the meaning of the constructivist approach in mediation, how it occurs and what is the role of mediator in the mediation process based on dialogue? The methodology of the study comprises a theoretical assessment of the role of the mediator based on a constructivist approach with a purposeful emphasis on a dialogue between parties. The mediator facilitates a dialogical mediation process being also a pedagogue who helps the parties to learn how to keep a dialogue. Analysis of the mediator's role and the usage of D.A. Kolb's learning types in the stages of mediation are the main results of the study. The significance of the study implies a substantiation of various roles of the mediator, constructivist approach with the emphasis on the dialogue and implementation of D.A. Kolb's learning types in the stages of mediation.
\end{abstract}

Keywords: mediation, constructivism, a mediator's roles, dialogue, transformative learning.

\section{Introduction}

People relations in everyday life and work conditions depend on communication to a large extent and that is why also differences arise which may provoke hostile, antagonistic attitude against each other that, in their turn, lead to the conflict. N. Luhmann highlights the idea that to the degree of the complexity of the social system growth, the differences become increasingly to be the subject of communication (Luhmann, 1996) and L.A. Coser and R. Fisher explains that there is a distinction between the conflict and a hostile or antagonistic attitude. The social conflict - it always is a social interaction, whereas the attitude or feeling is only a precondition for activity (Coser, 1957; Fisher, 2000).

Conflicts can be resolved differently. When resolving conflicts in a constructive way, that is, to disclose unknown things, facts, involved parties' interests, needs, opinions and experience, additional knowledge is obtained. This knowledge enables to resolve the conflict to break the deadlock over communication. Thus, it can be assumed that the conflict situation has arisen because of insufficient knowledge. The solution was possible by gaining additional knowledge. The conflict resolution may be reached in different ways, in court or alternatively through negotiations, discussions, reconciliation (Lewicki, Weiss, Lewin, 1992) or conducting a mediation process with the third-party therapeutic role (Kelman, 2015).

The authors have examined the concept of mediation and the philosophy of dialogue, nature, components, barriers and benefits (Portere, Briede, 2019b), and further investigations highlight the idea that the functions of the mediation process are not only finding a constructive conflict solution and maintaining and improving relationship, but also constructive learning about the world and relations, acquisition and approbation of new knowledge. This learning is based on constructive paradigm and the role of importance of dialogue (discourse) outlined as the instrument of learning. Having regard that the dialogue (discourse) is an integral part of mediation, consequently, it is possible to reflect the mediation based on constructivism as an instrument of adult learning.

In the process of the study the aim was to find out theoretical explanations of the meaning of constructivist approach in mediation, how it occurs and what is the role of the mediator based on dialogue in the process of mediation. 


\section{Methodology}

According to the aim the research question is how learning could be carried out using constructive approach and transformative learning theory, and what are the roles of the mediator based on dialogue in the process of mediation?

The objectives of the study were:

- to investigate the constructivist approach and transformative learning theory to substantiate learning and the mediator's roles in the process of mediation (Alderson-Day, Fernyhough, 2015; Bhattacharjee, 2015; Hermans, 2006; Mercer, 2020; Merriam, Bierema, 2013; Mezirow, 1997; Mezirow, 2003; Sulistyowati, 2019; Watzlawick, 1977);

- to substantiate the usage of D.A. Kolb's learning styles in the stages of mediation (Kolb, Kolb, 2013);

- to substantiate the mediator's roles based on dialogue in the process of mediation (Buber, 2003; Elliott, 2016; Habermas, 1999; Hermans, 2006; Hermans, Hermans-Konopka, 2010; Kaufman, 2019; Lewitter, Bourne, Attwood, 2019; Macmillan, 2012; Portere, Briede, 2019b; Portere, Morevs, 2020a, 2020b; Taylor, Cranton, 2012).

The principal method of the study was the theoretical analysis of constructivist approaches including adult transformative learning described by the American sociologist, professor J. Mezirow (Mezirow, 1997) and the American educational theorists D.A. Kolb and A.Y. Kolb (Kolb, Kolb, 2013) about the adult learning model and its four aspects, and how they are implemented in the process of constructive learning. The roles of the mediator in the process of mediation were examined in the frame of constructive and transformative learning.

\section{Results and Discussion}

\section{The meaning of constructivist approach in the process of mediation}

Constructivism (from Latin constructio-construction) - a scientific trend on the basis of which the notion lies about the activity of the subject of inquiry which uses experience, procedures of especial reflections (communications) creating (construing) images, concepts and judgments.

Constructivism is used in the theory of inquiry (epistemology) and philosophy of science, mathematics, sociology, psychology and pedagogy in the XX century. Substantiation how knowledge should be constructed to define some "truth" about the individual or collective learning and transformation is in the centre of constructive approach.

According to constructivism the individual's major difference lies in the fact that his being is not contemplative and even not simply active or functioning, but exactly constructive, creatively constantly creating himself. Radical constructivist P. Watzlawick wrote that "the belief that one's own view of reality is the only reality is the most dangerous of all delusions" (Watzlawick, 1977, 13).

Nowadays constructivism experiences new development is based on special sciences, including the science of the individual (Alderson-Day, Fernyhough, 2015). In such a way the cognitive, radical, social, critical, cultural and other trends of constructivism arise. For example, "Cognitive Constructivism is based on beliefs, previous knowledge, values and self - concept and deals with how an individual constructs his understanding of the world around him" (Sulistyowati, 2019, 94) and it happens through deep learning (Mercer, 2020).

The primary condition for human existence is to understand the meaning of our experience, as well as to act at cognitive level acquiring the mechanisms of "critical thinking" (Magno, 2010) to monitor the perception, analysis and transfer of information, namely, communication. Consequently K. Oganisjana and R. Ozols have worked out the co-development model of metacognitivity and thinking putting emphasis on eight mutually linked "pillars: senses, perception, emotions, imagination, language, action, experience, and knowledge which have an impact on each individual's action" and which are crucial in developing dialogue in mediation (Oganisjana, Ozols, 2018, 18-19). 
J. Bhattacharjee analysing constructivist approach to learning stresses such "guiding principles" as "search for meaning, active construction of meaning, understanding wholes and parts, understanding of students' mental models, making the assessment part of the learning process" (Bhattacharjee, 2015, 66).

Nowadays constructivist approach postulates free expression of the individual's experience and motivated construction of knowledge, and it could be a positive turn in a mediation process because individuals' openness is fostered. That is why a mediator who uses the ideas of constructivist approach could be more effective in helping parties to solve problems. It can be done if conflicting sides are promoted to express, understand and reinterpret their experience thinking about their actions and decisions. The usage of transformative learning theory is a way where a particular stress is put on free expression of ideas and experiences, and development of dialogical relations.

\section{The meaning of transformative learning in the process of mediation}

Transformative learning - and "the approach" to learning based on "creating the conditions for and the skills of effective adult reasoning and the disposition for transformative learning — including critical reflection and dialectical discourse - is the essence of adult education and defines the role of the adult educator, both as a facilitator of reasoning in a learning situation and a cultural activist fostering the social, economic, and political conditions required for fuller, freer participation in critical reflection and discourse by all adults in a democratic society" (Mezirow, 2003, 62-63).

Besides, the "prospective transformation" process of the learners' personality has three measurements: psychological, values and behaviour. It corresponds to the changes of self-awareness, confidence systems and lifestyle. This process of change is rational and analytical. It occurs when people transform the values of their experience and knowledge on the basis of critical reflection. The conversation participants meaning scheme (beliefs, relations, emotional reactions) changes. The meaning schemes that make up meaning structures may change as an individual adds to or integrates ideas within an existing scheme and, in fact, this transformation of meaning schemes occurs routinely through learning.

J. Mezirow posits that when circumstances permit, transformative learners move toward a frame of reference that is more inclusive, discriminating, self-reflective, and integrative of experience (Mezirow, 1997).

The theory of transformative learning developed by J. Mezirow is described that through it "We transform our frames of reference through critical reflection on the assumptions upon which our interpretations, beliefs, and habits of mind or points of view are based" (Mezirow, 1997, 7).

The transformative learning has two basic kinds of learning: instrumental and communicative learning. Instrumental learning is focused on learning through task-oriented problem solving and determination of cause-and-effect relationships (Merriam, Bierema, 2013). Communicative learning involves how individuals communicate their feelings, needs and desires.

J. Mezirow distinguishes four principles of adult learning:

- elaborating of schemes in which the learners are directly engaged in the learning process;

- examining the true problems or situations;

- critical approach to contemplation about experience;

- interaction with other learners (Mezirow, 1997).

The socialized individual comes in touch with other individuals every day the interaction and communication occur. The communication is a complicated process because each individual involved in it which is specific, unique.

H.J.M. Hermans proposed to emphasize:

- the area of internal "I"; my roles, versions - social (wife, psychotherapist, citizen) or personality (vegetarian, dreamer, art house fan);

- the area of external "I"; the interiorized others imagined or real; from past, present or future; certain people and entire societies; for example: mother and father or child to be born; teacher, pupils, colleagues or authors of books or films; the internal and external areas together exactly constitute "I" as a mini society; 
- the society - "real others", the people around, and all three areas are in the process of change communication (Hermans, 2006).

In modern society we have to learn to make our interpretations instead of acting in accordance with the goals, attitudes, judgments and feelings of others. The collaboration for such understanding is the main goal. Transformative learning itself develops the autonomous thinking on the basis of explanation, validation and reformulation of the nature of their experience.

\section{Dialogue as a result of implementation of constructive and transformative learning in mediation}

The dialogue is the main form of communication of the social subject, and the dialogue also becomes the main instrument in the process of conflict resolution in mediation. Dialogue has five features: mutuality, propinquity, empathy, risk, and commitment (Capizzo, 2018). M. Buber underlines three types of dialogue in which people communicate:

- genuine whether spoken or silent where each of the participants really has in mind the other or others in their present and particular being and turns to them with the intention of establishing a living mutual relation between himself and them;

- technical prompted by the need of objective understanding;

- monologue disguised as dialogue in which two men, meeting in space, speak each to himself in strangely tortuous and circuitous ways and yet imagine they have escaped the torment of being thrown back on their own resources (Buber, 2003).

Due to the own unique nature, dialogue helps to explain the complex processes through the context in which we are alive, challenge the reflection and express encountered thoughts. To succeed a good dialogue, a positive attitude and undivided attention among the participants of the dialogue are required (Soika, 2017). The dialogue "is the basis for mutual cooperation, conflict resolution, promoting reflection, and inspiring new, creative ideas and actions" (Soika, 2020, 451).

The conditionality is distinguished between internal and external when all merge in the process of dialogue. However, not any communication is meant as dialogue. H.J.M. Hermans and A. HermansKonopka propose to examine the dialogue in contrast to "the monologue" and include in it:

- listening to everybody's opinion;

- allocation of area to disclose each own experience or opinion;

- interest in identification of possible non-understanding and desire to correct it;

- readiness to learn from each other on the basis of mutual exchange (Hermans, HermansKonopka, 2010).

\section{The mediator's roles based on dialogue in the process of mediation}

The authors consider that during the mediation process the mediator plays not only the role of intermediary, but also the important role of the teacher (pedagogue) who shows and teaches the type of communication and structure for conflict resolution to the parties involved in the conflict. From this point of view the mediation process can be regarded as a learning process and, precisely, the adult further education process. At the moment when the conflicting parties have reached a deadlock as a result of insufficient knowledge, this is the right moment to learn something new useful.

O. Kaufman characterizes his work as a mediator as follows "Because I am working with two adults, as opposed to one, and they are human and not canines this is always a delicate, complex and nuanced balancing act. However, what we can learn from dog training is that the response we are trying to evoke is not generally a natural response and that our job as mediators may involve some behaviour modification and client retraining so that the process stays on the level of rational rather than instinctive/reactive" (Kaufman, 2019).

The teacher becomes a facilitator who gives a task to the participants of the conversation to construct knowledge about themselves, about other people and social norms. As a result, the participants play a significant role in the learning environment and process (Taylor, Cranton, 2012). The same idea can be applied to the mediation process where a mediator promotes clients to be active participants through a dialogue. 
The mediator is a person who determines and conducts the mediation process, so that the parties involved in the conflict obtain the necessary information understanding to reach the conflict resolution which as fully as possible realizes their expectations and needs in the existing reality.

I. Kokle-Narbuta in her study has underlined the pedagogue paradigm based on constructivism used also by the mediator in mediation "the pedagogue is no longer an expert, but acts as a coordinator pedagogue - creates a dialogue, encourages, contributes, assists - that radically contrasts with the traditional learning environment" (Kokle-Narbuta, 2018, 60).

In mediation various types of dialogues are used which enhance mutual understanding and collaboration, respect and tolerance, improvement of relationship culture, inquiry of the facts of situation and reaching agreement (as discourse) (Portere, Morevs, 2020b). Having regard that the mediation is a constructive process and the methods of dialogue (discourse) are used there, we can talk about constructivism of the mediation (Portere, Morevs, 2020a)

The aspects of principal constructive approaches are as follows:

- dialogue and its type - discourse, which is an instrument of reaching agreement by the conflicting parties;

- intervention of a constructive mediator conducting the discourse;

- assistance to the participants of the conflict is to overcome phonetic, semantic, logic and stylistic barriers, that is, to achieve a shared understanding of denotations;

- constructive mediation process which provides for creation or renewal of constructs for reaching agreement;

- testing of participants of mediation (questionnaire) and processing of results;

- the role of mediator as middleman in the process of conflict resolution and reaching agreement that may be comparable with the role of teachers in the learning process;

- constructive learning process of the conflicting parties and the mediators (Portere, Morevs, 2020a).

The mediator in the conflict is not only a mediator, a magistrate or a moderator, but also a teacher who, by his example and explanations, can teach the conflicting parties (Portere, Briede, 2019a), and his important skill to conduct the dialogue is taught to the conflicting parties. The components of dialogue are taken into consideration: partner genuineness, emphatic understanding, active listening, full presence, spiritual and mutual equality, eye contact, clear expression of information, interaction, listening and hearing, trusting the world and other people, connection with the surrounding world, responding to a dialogical situation, deep feeling of one's own "Me", high level of rational thinking, high level of reflection, autonomous individual behaviour, individual position and doubt of it, be able to change one's personality, be able to recognize own lack of knowledge or weakness, be able to ask for help from another person and receive I, equality, tolerance, fresh ideas (Portere, Briede, 2019b).

A mediator's role often is explained using more than one word, for example, mediation expert D. Silvera mentions that "mediators are generally lawyers, psychologists, educators or community leaders, or any mature adult with life experience - priding themselves on their impartiality and neutrality". Multiple roles are a basis for their features:

- skilfully facilitate a structured communication process;

- establish a polite atmosphere in difficult circumstances;

- demonstrate empathy and respect;

- empower the parties to express themselves;

- encourage the parties to listen to each other;

- aspire towards impartiality;

- leave all decision making to the parties;

- be aware of and manage own values;

- be prepared to tolerate ambiguity (Silvera, 2006). 
F. Elliott mentions similar features emphasizing the mediator's managerial skills in the process. He or she should take control of the process and aid the parties to settlement. The Centre for Effective Dispute Resolution states that the mediator fulfils several important roles during the mediation and should:

- manage the process firmly but sensitively;

- facilitate the parties towards settlement by overcoming deadlock;

- gather information to identify common goals;

- be a reality tester, helping the parties to take a realistic view of the dispute;

- act as a problem solver, thinking creatively to help the parties construct an outcome that best meets their needs;

- soak up the feelings of parties and frustrations, re-channelling the parties' energy into positive approaches to the issues;

- act as a scribe who assists in the writing of the agreement;

- be a settlement supervisor, checking that the settlement agreement has worked and being available to help with further problems that may occur;

- prompt the parties towards settlement and keep the momentum towards settlement (Elliott, 2016).

While J. Habermas indicates the existence of discussions and argumentations in all cultures but at the same time it is a big problem to keep neutrality (Habermas, 1999). That is why the role of the meditator is crucial because one angle of it is to enhance stable flow of dialogue.

Each person in the conflict should be respected, as all other persons and should remember that others may have different and valuable perspectives based on their past experience (Lewitter, Bourne, Attwood, 2019)

The mediator's role as the adult pedagogue's role is interactive, based on dialogue, such as to:

- assist the parties to overcome miscommunication, misunderstanding and confusion by helping them clarify what is agreed and disputed, and identifying the underlying issues;

- develop awareness of the real needs of those who are involved by drawing out information and probing each party for their underlying interests;

- help the parties to generate and evaluate options to resolve the dispute;

- be a sounding board and reality check for parties to reflect on the reasonableness of their positions and demands and alternative approaches;

- facilitate communication and motivate the parties to find a way to work co-operatively towards finding a mutually acceptable solution;

- build on areas of agreement and assist parties to craft a satisfactory and effective settlement (Macmillan, 2012, 4).

Considering theoretical investigations of adult learning processes and styles, constructivism and constructivism in mediation, we can, firstly, to define the components of constructive adult learning in the conflict resolution in the mediation process conducted by the mediator:

- during the mediation process the parties learn to reach solution of their conflict; at the beginning the terms of the process and the facts of the situation should be agreed upon;

- the value of mediation is interests, maintained or renewed relations of the parties, which result in the conflict resolution;

- the materials of learning are the cognitive constructs of the parties and signs of conflict situation;

- learning takes occurs the basis of the existing knowledge, experience and the mediator's skills and knowledge, the multifaceted view of the situation and skills of dialogue;

- the mediator creates a dialogue with the parties and among the parties and helps to the parties to construe their own knowledge and change their constructs and find solutions of the conflict.

Considering the above-mentioned theoretical concepts and the authors' experience in mediation processes it is possible to mention the following roles of the mediator: makes the conflict multifaceted, enhances dialogue and understanding, brings closer the conflicting parties, helps the parties involved in the conflict to come closer to the reality, reduces the level of emotions, creates helping relationship, provides concepts of social science and science of conflictology, psychology, without assessment of the 
parties; conducts the discourse in the area determined by the conflicting parties; serves as example of communication for the conflicting parties.

The mediator must be able to help and teach the parties to the conflict:

- take a critical look at the conflict situation, examining the causes and potential consequences of

- the situation;

- understand parties' needs and expressing itself clearly about them;

- enhance hearing and understanding the expressions of needs of a partner by accepting a companion as a unique personality with his/her own experience;

- negotiate constructively on the subject set by mediation, with a view to finding a solution that

- would bring satisfaction to all parties involved in the conflict;

- learn the skills of non-violent, constructive dialogue for future conflict situations.

Transformative learning is a way how to make a mediator's role more effective. The purpose of the transformative learning is to achieve the learner's perspective transformation which may be more often reached on the basis of disorienting dilemmas triggered by a life crisis or major life transition, and rarely on the basis of the accumulation of transformations in the learner's meaning schemes.

D.A. Kolb in his theory of learning styles includes four stages of learning which in their turn form the learning cycle: concrete learning, reflective observation, abstract conceptualization and active experimentation. The learning process is integrated, where each subsequent stage of learning supports and enhances each other (Kolb, Kolb, 2013). In Mediation process D.A. Kolb's (Kolb, Kolb, 2013) theory of learning style may be observed very explicitly, because the parties involved in the conflict initially show their experience (attitudes) about the conflict situation, then encounter the experience of the opposite party about the same conflict, thus gaining new experience - new knowledge. At the next stage the conflicting parties try abstractly to reach the possible conflict resolutions. And at the end they reach the agreement which has to be implemented in reality and to provide solution of the conflict and peace.

Developing the theory of the four learning styles, D.A. Kolb and A.Y. Kolb define nine learning styles: initiating, experiencing, imagining, acting, balancing, reflecting, deciding, thinking and analysing. The parties involved in mediation use all nine styles creating perfect space for Conversational Learning characterized as follows: Conversational Learning describes the dimensions of spaces that allow for good conversation. Good conversation is more likely to occur in spaces that integrate thinking and feeling, talking and listening, leadership and solidarity, recognition of individuality and relatedness and discursive and recursive processes. When the conversational space is dominated by one extreme of these dimensions, e.g., talking without listening, conversational learning is diminished (Kolb, Kolb, 2013).

The stages of mediation process can be applied to D.A. Kolb's learning styles (Table 1). The types of learning of adult conflict resolution in the mediation process may be reflected examining a structured mediation process by D.A. Kolbs's styles. They help to orientate in dialogue learning and the roles of the mediator.

Table 1

Usage of D.A. Kolb's learning styles in the stages of mediation (developed by the authors)

\begin{tabular}{|l|l|l|}
\hline \multicolumn{1}{|c|}{ Stage of mediation process } & \multicolumn{1}{|c|}{ Key elements of stage } & $\begin{array}{c}\text { Applied learning style } \\
\text { according to D.A. Kolb }\end{array}$ \\
\hline $\begin{array}{l}1^{\text {st }} \text { stage - introduction with the } \\
\text { mediation process }\end{array}$ & $\begin{array}{l}\text { Awareness of the lack of existing knowledge } \\
\text { and skills and the benefits of the desired } \\
\text { (possible) knowledge and skills }\end{array}$ & $\begin{array}{l}\text { Getting to know the } \\
\text { possibility to resolve the } \\
\text { conflict constructively }\end{array}$ \\
\hline $\begin{array}{l}2^{\text {nd }} \text { stage - clarification of } \\
\text { positions. Inquiry of known and } \\
\text { unknown }\end{array}$ & $\begin{array}{l}\text { Concrete experience (subjective view on } \\
\text { situation) verbalization (awareness) }\end{array}$ & Specific experience \\
\hline $\begin{array}{l}3^{\text {rd }} \text { stage - awareness of the self, } \\
\text { the other }\end{array}$ & $\begin{array}{l}\text { Expansion of experience, expansion of the } \\
\text { view on the situation with inclusion of the } \\
\text { self, others, conditions, possibilities }\end{array}$ & Reflexive observation \\
\hline $4^{\text {th }}$ stage - finding solutions & Consideration of various options & Abstract conceptualization \\
\hline $\begin{array}{l}5^{\text {th }} \text { stage }- \text { formulating the best } \\
\text { option }\end{array}$ & $\begin{array}{l}\text { Linking, adjusting desires and conditions }- \\
\text { the legal, social framework of agreement }\end{array}$ & Active experimentation \\
\hline
\end{tabular}




\section{Conclusions}

The mediator's roles are a constellation of knowledge, skills and attitudes about the social interaction of an individual and environment ensuring the mediator's ability to support the individual in conflict resolution and conduct a preventive action based on the method of dialogue.

Constructivist approach with the emphasis on dialogue and implementation of D.A. Kolb's learning styles in the stages of mediation contribute to this process so that parties can more successfully solve conflicts. Further usage of the learning styles should be investigated in the mediation process.

Mediation is a process where a mediator as a neutral person can implement a teacher's role and facilitate party's education how to meet their needs in a constructive way.

A mediator has to help and teach parties in the mediation situation looking critically at the conflict, examining the causes and potential.

\section{Acknowledgement}

The article was supported by LLU programme "Strengthening of Scientific Capacity LLU" scientific project No. Z-47 "Assessment of the Usage of Mediation Models and Mediators' Further Education Methodology “Terms 01/06/2020-31/05/2022

\section{Bibliography}

1. Alderson-Day B., Fernyhough C. (2015). Inner Speech: Development, Cognitive Functions, Phenomenology, and Neurobiology. Psychological Bulletin, 141(5), 931-965. doi: 10.1037/bul0000021

2. Bhattacharjee J. (2015). Constructivist Approach to Learning - an Effective Approach to Teaching Learning. International Research Journal of Interdisciplinary \& Multidisciplinary Studies, 1(6), 65-74. Retrieved from http://oaji.net/articles/2015/1707-1438677336.pdf

3. Buber M. (2003). Two Types of Faith. Syracuse University Press.

4. Capizzo L.W. (2018). Reimagining dialogue in public relations: Bakhtin and open dialogue in the public sphere. Public Relations Review, 44(4), 523-532. doi: 10.1016/j.pubrev.2018.07.007

5. Coser L.A. (1957). Social Conflict and the Theory of Social Change. The British Journal of Sociology, 8(3), 197-207. doi: 10.2307/586859

6. Elliott F. (2016). Mediation Guide - the Basics. Retrieved from https://www.fenwickelliott.com/file/1754/download?token=IYqLyUCU

7. Fisher R. (2000). Sources of Conflict and Methods of Conflict Resolution. Retrieved from http://www.communicationcache.com/uploads/1/0/8/8/10887248/sources_of_conflict_and_methods_ of_resolution.pdf

8. Habermas J. (1999). Moral Consciousness and Communicative Action. Cambridge: MIT Press.

9. Hermans H.J.M. (2006). Moving through three paradigms, yet remaining the same thinker. Counselling Psychology Quarterly, 19(1), 5-25. doi: 10.1080/09515070600589735

10. Hermans H.J.M., Hermans-Konopka A. (2010). Dialogical self-theory: Positioning and counterpositioning in a globalizing society. Cambridge University Press. doi: 10.1017/CBO9780511712142

11. Kaufman O. (2019). Can You Teach an Old Dog New Tricks? Mediate. Retrieved from https://www.mediate.com/articles/kaufman-can-you-teach.cfm

12. Kelman H.C. (2015). The Development of Interactive Problem Solving: In John Burton's Footsteps. Political Psychology, 36(2), 243-262. doi: 10.1111/pops.12265

13. Kokle-Narbuta I. (2018). Ģimenূu izglìtība bērnu ar speciālām vajadzībām dzīves kvalitātes pilnveidei [Family Education for Improvement of Children's with Special Needs Quality of Life]. Promocijas darbs [Doctoral Thesis]. Latvijas Lauksaimniecības universitāte, Tehniskā fakultāte, Izglìtīibas un mājsaimniecības institūts. (in Latvian)

14. Kolb A.Y., Kolb D.A. (2013). The Colb Learning Style Inventory 4.0. Retrieved from https://learningfromexperience.com/downloads/research-library/the-kolb-learning-style-inventory-4$0 . p d f$

15. Lewicki R.J., Weiss S.E., Lewin D. (1992). Models of conflict, negotiation and third party intervention: A review and synthesis. Journal of Organizational Behavior, 13(3), 209-252. doi: $10.1002 /$ job.4030130303 
16. Lewitter F., Bourne P.E., Attwood T.K. (2019). Ten Simple Rules for avoiding and resolving conflicts with your colleagues. PLoS Computational Biology, 15(1), e1006708. doi: 10.1371/journal.pcbi.1006708

17. Luhmann N. (1996). Social Systems. Stanford University Press.

18. Macmillan R. (2012). A Practical Guide for Mediators. Geneva - New York: Macmillan Keck. Retrieved from http://macmillankeck.net/media/pdf/A\%20Practical\%20Guide\%20for\%20Mediators.pdf

19. Magno C. (2010). The role of metacognitive skills in developing critical thinking. Metacognition and Learning, 5(2), 137-156. doi: 10.1007/s11409-010-9054-4

20. Mercer R. (2020). Teacher Training, Beliefs, and Use of a Constructivist Learning Environment Supported by Instructional Technology. (Doctoral Thesis, The University of Southern Mississippi, Hattiesburg, MS). Retrieved from https://aquila.usm.edu/dissertations/1792/

21. Merriam S.B., Bierema L.L. (2013). Adult Learning: Linking Theory and Practice. Jossey-Bass Publishers.

22. Mezirow J. (1997). Transformative Learning: Theory to Practice. New Directions for Adult and Continuing Education, 74, 5-12. Jossey-Bass Publishers. Retrieved from https://www.ecolas.eu/eng/wp-content/uploads/2015/10/Mezirow-Transformative-Learning.pdf

23. Mezirow J. (2003). Transformative Learning as Discourse. Journal of Transformative Education. 1(1), 58-63. doi: 10.1177/1541344603252172

24. Oganisjana K., Ozols R. (2018). Metakognitivitāte, domāšanas astoṇi pīlāri un to ietekme uz indivīda rīcību [Metacognitivity, Eight Pillars of Thinking and their Impact on the Individual's Behaviour]. In Rekomendācijas konfliktu un problēmsituāciju risināšanai [Recommendations for Solving Conflicts and Problem Situations]. Rīga: IZM, PuMPuRS. Retrieved from http://www.pumpurs.lv/sites/default/files/2019-

12/05_PuMPuRS_infomaterials_Rekomendacijas_konfliktu_risinasanai.pdf\#page=15 (in Latvian)

25. Portere V., Briede B. (2019a). Conflict management models in the context of constructivism in mediation. In the Proceedings of the International Scientific Conference Research for Rural Development, 2. Jelgava: Latvia University of Life Sciences and Technologies, 260-267. doi: 10.22616/rrd.25.2019.078

26. Portere V., Briede B. (2019b). Importance of Dialogue Nature in the Mediator's Competence. In V. Dislere (Ed.), The Proceedings of the International Scientific Conference Rural Environment. Education. Personality (REEP), 12. Jelgava: Latvia University of Life Sciences and Technologies, 146-151. doi: 10.22616/REEP.2019.018

27. Portere V., Morevs V. (2020a). Constructivism in Mediation. In V. Dislere (Ed.), The Proceedings of the International Scientific Conference Rural Environment. Education. Personality, 13. Jelgava: Latvia University of Life Sciences and Technologies, 258-265. doi: 10.22616/REEP.2020.031

28. Portere V., Morevs V. (2020b). Dialogue as a Sign of Constructiveness in Mediation. In the Proceedings of the International Scientific Conference Research for Rural Development, 35 Jelgava: Latvia University of Life Sciences and Technologies, 296-302. doi: 10.22616/rrd.26.2020.043

29. Silvera D. (2006). Mediation and its Role in Adult Education. Mediate. Retrieved from https://www.mediate.com/articles/silveraD1.cfm

30. Soika I. (2017). Conditions for Use of Dialogue Method of Students' Career Guidance in Secondary Vocational Education. In V. Dislere (Ed.), The Proceedings of the International Scientific Conference Rural Environment. Education. Personality, 10. Jelgava: LLU, 255-262. Retrieved from https://lufb.llu.lv/conference/REEP/2016/Latvia-Univ-Agricult-REEP-2016proceed2255-808X-255-262.pdf

31. Soika I. (2020). Goals of the Dialogue of Students Career Guidance in Vocational Secondary Education. In V. Dislere (Ed.), The Proceedings of the International Scientific Conference Rural Environment. Education. Personality, 13. Jelgava: Latvia University of Life Sciences and Technologies, 450-457. doi: 10.22616/REEP.2020.053

32. Sulistyowati T. (2019). Bottom-up and Top-dowm Listening Processes within Cognitive Constructivist Learning Theory. PROMINENT Journal, 2(1), 92-100. Retrieved from https://jurnal.umk.ac.id/index.php/Pro/article/download/2962/1555

33. Taylor E.W., Cranton P. (2012). The Handbook of Transformative Learning: Theory, Research, and Practice. Jossey-Bass Publishers.

34. Watzlawick P. (1977). How Real Is Real?: Confusion, Disinformation, Communication. Random House Inc. 